\title{
Supporting Information for Development and Application of an Efficient Medium for Chromogenic Catalysis of Tetramethylbenzidine with Horseradish Peroxidase
}

Meng Li, ${ }^{\dagger}$ Haiping Su, ${ }^{\dagger}$ Yan Tu, Yazhuo Shang, ${ }^{* \dagger}$ Yu Liu, ${ }^{*}+$ Changjun Peng, ${ }^{\dagger}$ Honglai Liu

$\dagger$ Key Laboratory for Advanced Materials, School of Chemistry and Molecular Engineering, East China University of Science and Technology, Shanghai 200237, China

* State Key Laboratory of Chemical Engineering and School of Chemical Engineering, East China University of Science and Technology, Shanghai 200237, China

* Corresponding author. E-mail: shangyazhuo@ecust.edu.cn.

* Corresponding author. E-mail: liuyu@ecust.edu.cn 
Optimization experiment

Substrate specificity tests (Table S1)

S3-S4

Viscosity measurements

S4-S5

The derivation of rate limiting step

(Table S2)

S5-S6

Figure S1

S7

Figure S2

S7

Figure S3

S8

Figure S4

S8

Table S3

S9

References

S9-S10 
1. The optimization of $\mathrm{SDS}_{/}\left[\mathrm{C}_{4} \mathrm{mim}\right]\left[\mathrm{BF}_{4}\right]$ medium. The concentration optimization of $\mathrm{SDS} /\left[\mathrm{C}_{4} \mathrm{mim}\right]\left[\mathrm{BF}_{4}\right]$ in the mediums: firstly, fixed the SDS concentration at $2.5 \mathrm{mM}$ and varied $\left[\mathrm{C}_{4} \mathrm{mim}\right]\left[\mathrm{BF}_{4}\right]$ concentration $(0,0.5,2.5,7.5$ and $12.5 \mathrm{mM}$ ) to obtain the $\mathrm{SDS} /\left[\mathrm{C}_{4} \mathrm{mim}\right]\left[\mathrm{BF}_{4}\right]$ combination with different molar ratios, in which the catalysis were carried out using $200 \mu \mathrm{M}$ TMB, $2 \mathrm{mM} \mathrm{H}_{2} \mathrm{O}_{2}$ and $0.05 \mu \mathrm{g} / \mathrm{mL}$ HRP at $\mathrm{pH}$ of 7.4 and temperature of $25 \pm 0.1{ }^{\circ} \mathrm{C}$ unless otherwise stated, recorded the time-dependent UV-vis absorbance at $652 \mathrm{~nm}$ in $5 \mathrm{~min}$; Then, fixed $\left[\mathrm{C}_{4} \mathrm{mim}\right]\left[\mathrm{BF}_{4}\right]$ concentration at $2.5 \mathrm{mM}$ and varied SDS concentration $(0,0.5,2.5,7.5$ and $12.5 \mathrm{mM})$ and processed the same procedures above.

The $\mathrm{pH}$ optimization of $\mathrm{SDS} /\left[\mathrm{C}_{4} \mathrm{mim}\right]\left[\mathrm{BF}_{4}\right]$ combination: Took the $\mathrm{SDS} /\left[\mathrm{C}_{4} \mathrm{mim}\right]\left[\mathrm{BF}_{4}\right]$ combination of optimal concentration above $(2.5 \mathrm{mM}$ SDS, 2.5 $\left.\mathrm{mM}\left[\mathrm{C}_{4} \mathrm{mim}\right]\left[\mathrm{BF}_{4}\right]\right)$ as mediums in the following experiments. Firstly, the $\mathrm{SDS} /\left[\mathrm{C}_{4} \mathrm{mim}\right]\left[\mathrm{BF}_{4}\right]$ combination with different $\mathrm{pH}(4.0,5.0,6.0,7.4,8.0)$ were prepared, in which carried out the reaction using $500 \mu \mathrm{M} \mathrm{TMB}, 2 \mathrm{mM} \mathrm{H}_{2} \mathrm{O}_{2}$ and 0.05 $\mu \mathrm{g} / \mathrm{mL}$ HRP. After the reaction equilibrium, recorded the UV-vis absorbance at 652 $\mathrm{nm}$. The same procedures were carried out in the control experiments using PBS as medium.

2. The substrate specificity tests in $\mathbf{S D S} /\left[\mathrm{C}_{4} \mathrm{mim}\right]\left[\mathrm{BF}_{4}\right]$ combinations. The five different substrates of HRP, including TMB, OPD, ABTS, ODA and 5-AS respectively, which usually used in ELISA were selected to study the substrate specificity in $\mathrm{SDS} /\left[\mathrm{C}_{4} \mathrm{mim}\right]\left[\mathrm{BF}_{4}\right]$ combinations. The experiment groups were divided into A-E as Table S1 shows, which provided the required regents and reaction conditions referred 
from literatures for the subsequent steps. ${ }^{1-3}$ Firstly, the substrates were dissolved the in the corresponding solvents (Table S1) to obtain the desired stock solutions. Subsequently, substrates stock solutions were added into $\mathrm{SDS} /\left[\mathrm{C}_{4} \mathrm{mim}\right]\left[\mathrm{BF}_{4}\right]$ combinations of optimum $\mathrm{pH}$ respectively to obtain the solutions containing the same concentration of substrates $(200 \mu \mathrm{M})$, then, for the systems A-E, equivalent HRP $(0.05$ $\mu \mathrm{g} / \mathrm{mL})$ and $\mathrm{H}_{2} \mathrm{O}_{2}(2 \mathrm{mM})$ were added to obtain the reaction solutions. After $15 \mathrm{~min}$, the reactions were stopped by adding corresponding stop solutions if necessary, recorded the OD value at the corresponding wavelength according to Table S1 after reaction for $30 \mathrm{~min}$. The same procedures were carried out in controlled experiments using conventional mediums of PBS.

Table S1. The reaction conditions and detection conditions for the catalysis of HRP with different substrates ${ }^{1-3}$

\begin{tabular}{|c|c|c|c|c|c|c|c|}
\hline group & substrate & $\begin{array}{l}\text { substrate } \\
\text { solvent }\end{array}$ & $\begin{array}{c}\text { chromogenic } \\
\text { medium }\end{array}$ & pH & $\begin{array}{c}\text { stop } \\
\text { solution }^{a}\end{array}$ & $\begin{array}{c}\text { detection } \\
\text { wavelength } \\
\text { (nm) }\end{array}$ & $\begin{array}{c}\text { color } \\
\text { developing } \\
\text { time (min) }\end{array}$ \\
\hline \multirow{2}{*}{ A } & \multirow{2}{*}{ TMB } & DMSO & $\mathrm{SDS} / \mathrm{C}_{4}$ & 7.4 & - & 652 & 5 \\
\hline & & DMSO & PBS & 5.0 & $\mathrm{H}_{2} \mathrm{SO}_{4}$ & 450 & 30 \\
\hline \multirow{2}{*}{ B } & \multirow{2}{*}{ OPD } & PBS & $\mathrm{SDS} / \mathrm{C}_{4}$ & 5.0 & $\mathrm{H}_{2} \mathrm{SO}_{4}$ & 492 & 30 \\
\hline & & PBS & PBS & 5.0 & $\mathrm{H}_{2} \mathrm{SO}_{4}$ & 492 & 30 \\
\hline \multirow{2}{*}{$\mathrm{C}$} & \multirow{2}{*}{ ABTS } & PBS & $\mathrm{SDS} / \mathrm{C}_{4}$ & 4.0 & $\mathrm{H}_{2} \mathrm{SO}_{4}$ & 414 & 30 \\
\hline & & PBS & PBS & 4.0 & $\mathrm{H}_{2} \mathrm{SO}_{4}$ & 414 & 30 \\
\hline \multirow{2}{*}{$\mathrm{D}$} & \multirow{2}{*}{ ODA } & methanol & $\mathrm{SDS} / \mathrm{C}_{4}$ & 5.0 & $\mathrm{HCl}$ & 400 & 30 \\
\hline & & methanol & PBS & 5.0 & $\mathrm{HCl}$ & 400 & 30 \\
\hline \multirow{2}{*}{$\mathrm{E}$} & \multirow{2}{*}{ 5-AS } & PBS & $\mathrm{SDS} / \mathrm{C}_{4}$ & 6.0 & $\mathrm{NaOH}$ & 449 & 30 \\
\hline & & PBS & PBS & 6.0 & $\mathrm{NaOH}$ & 449 & 30 \\
\hline
\end{tabular}

${ }^{a}$ the concentration of $\mathrm{H}_{2} \mathrm{SO}_{4}, \mathrm{HCl}$ and $\mathrm{NaOH}$ solutions used as stop solutions is 2 $\mathrm{mol} / \mathrm{L}, 5 \mathrm{~mol} / \mathrm{L}$ and $1 \mathrm{~mol} / \mathrm{L}$ respectively.

3. Viscosity measurements of different mediums. Viscosities of different mediums were measured by Brookfield viscometer (DV-II, USA). The viscometer must be 
adjusted to level status before measurement. Firstly, the viscometer was zero set. Then, selected a proper rotor and fixed it onto the connecting rod. Next, $15 \mathrm{~mL}$ sample solution (PBS, $2.5 \mathrm{mM}$ SDS solution, $2.5 \mathrm{mM}$ SDS/ $2.5 \mathrm{mM}\left[\mathrm{C}_{\mathrm{n}} \mathrm{mim}\right]\left[\mathrm{BF}_{4}\right]$ combination $(\mathrm{n}=2,4,6,8,10))$ was added into a test tube and kept the solution covering the top of the rotors. Further, set a proper rotation rate and started testing. Finally, read a valid viscosity only if the torque value was in the range of $20 \%-90 \%$. The measuring temperature was controlled at $25 \pm 1{ }^{\circ} \mathrm{C}$ by a constant temperature water-bathing and the viscosity value of the sample (Table S2) was the mean value of the results of three parallel experiments.

4. The derivation of rate limiting step. The theory of the diffusion controlled reaction is referred from literature. ${ }^{4}$ Briefly, the diffusion coefficient of enzymes and substrates was calculated by Einstein-Stokes equation as eq 1:

$$
D=\frac{k_{B} T}{6 \pi \eta R}
$$

Where, $D$ is the diffusion coefficient of enzyme or substrates, $k_{B}$ is Boltzmann constant, $T$ is the absolute temperature $(298.15 \mathrm{~K}), \eta$ is dynamic viscosity of solution, $R$ is the radius of HRP $(3 \mathrm{~nm}), \mathrm{H}_{2} \mathrm{O}_{2}(0.3 \mathrm{~nm})$ or TMB $(0.5 \mathrm{~nm})$. Thus, diffusion coefficients of $\mathrm{H}_{2} \mathrm{O}_{2}\left(D_{H 2 O 2}\right)$ and TMB $\left(D_{T M B}\right)$ in different medium were obtained based on $e q 1$ and that were summarized in Table S2.

For the diffusion controlled reaction, the diffusion velocity constant $(k)$ can be expressed as eq 2

$$
k=4 \pi\left(D_{S}+D_{E}\right) r_{S E} N_{A}
$$


Where $k$ is the diffusion velocity constant, $D_{S}$ and $D_{E}$ are the diffusion coefficient of substrate and enzyme respectively. $r_{S E}$ is the centroid distance between the closed substrate and enzyme (approximately equals the sum of radius for substrate $\left(R_{S}\right)$ and enzyme $\left.\left(R_{E}\right)\right) . N_{A}$ is the Avogadro constant. We assumed that enzyme molecule is in a static state, thus, $k=4 \pi D_{S} r_{S E} N_{A} . k_{0}=k_{c a t} / K_{m}$, the ratio is the apparent second-order rate constant for the reaction between substrate and free enzyme. For the present system, $k_{0}$ can be figured out by the obtained data shown in Table 2, which is used for comparing with $k$ to determine the rate limiting step. If $k<<k_{0}$, diffusion is the rate limiting step, and vice versa. ${ }^{4}$

According to above discussion, the diffusion velocity constant of $\mathrm{H}_{2} \mathrm{O}_{2}$ and TMB $(k$ ${ }_{H 2 O 2}$ and $\left.k_{T M B}\right)$ as well as the $k_{0, H 2 O 2}$ and $k_{0, T M B}$ in different mediums are obtained and that are summarized in Table S2. Clearly, both $k_{\mathrm{H} 2 \mathrm{O} 2}$ and $k_{T M B}$ are greater than $k_{0, \mathrm{H} 2 \mathrm{O} 2}$ and $k_{0, T M B}$ as Table S2 shows, which confirm that substrate diffusion is not the ratelimiting step for the studied system.

Table S2 Summarization of parameters related to substrates diffusion in different mediums

\begin{tabular}{cccccccc}
\hline medium & $\begin{array}{c}\text { Viscosity } \\
(\mathrm{mPa} \cdot \mathrm{s})\end{array}$ & $\begin{array}{c}D_{\mathrm{H} 2 \mathrm{O} 2} \\
\left(\times 10^{-10} \mathrm{~m}^{2} / \mathrm{s}\right)^{a}\end{array}$ & $\begin{array}{c}k_{\mathrm{H} 2 \mathrm{O} 2} \\
\left(\times 10^{7} \mathrm{~L} /\right. \\
\mathrm{mol} \cdot \mathrm{s})^{b}\end{array}$ & $\begin{array}{c}k_{0, \mathrm{H} 2 \mathrm{O} 2}\left(\times 10^{7}\right. \\
\mathrm{L} / \mathrm{mol} \cdot \mathrm{s})^{c}\end{array}$ & $\begin{array}{c}D_{T M B} \\
\left(\times 10^{-10} \mathrm{~m}^{2} / \mathrm{s}\right)^{a}\end{array}$ & $\begin{array}{c}k_{T M B} \\
\left(\times 10^{7} \mathrm{~L} /\right. \\
\mathrm{mol} \cdot \mathrm{s})^{b}\end{array}$ & $\begin{array}{c}k_{0, T M B}\left(\times 10^{7}\right. \\
\mathrm{L} / \mathrm{mol} \cdot \mathrm{s})^{c}\end{array}$ \\
\hline $\mathrm{PBS}$ & 1.02 & 7.14 & 1.78 & 0.00217 & 4.28 & 1.13 & 0.0202 \\
$\mathrm{SDS}$ & 1.07 & 6.81 & 1.70 & 1.52 & 4.08 & 1.08 & 0.63 \\
$\mathrm{SDS} / \mathrm{C}_{2}$ & 1.09 & 6.68 & 1.67 & 1.20 & 4.01 & 1.06 & 0.71 \\
$\mathrm{SDS} / \mathrm{C}_{4}$ & 1.11 & 6.56 & 1.64 & 1.44 & 3.94 & 1.04 & 0.80 \\
$\mathrm{SDS} / \mathrm{C}_{6}$ & 1.18 & 6.17 & 1.54 & 1.29 & 3.70 & 0.98 & 0.76 \\
$\mathrm{SDS} / \mathrm{C}_{8}$ & 1.22 & 5.97 & 1.49 & 0.71 & 3.58 & 0.95 & 0.35 \\
$\mathrm{SDS} / \mathrm{C}_{10}$ & 1.35 & 5.39 & 1.35 & 0.62 & 2.24 & 0.86 & 0.23 \\
\hline
\end{tabular}


${ }^{a}$ Diffusion coefficient of $\mathrm{H}_{2} \mathrm{O}_{2}$ and TMB, ${ }^{b}$ diffusion velocity constant of $\mathrm{H}_{2} \mathrm{O}_{2}$ and TMB, ${ }^{c}$ apparent second-order rate constant between HRP and $\mathrm{H}_{2} \mathrm{O}_{2} / \mathrm{TMB}$.
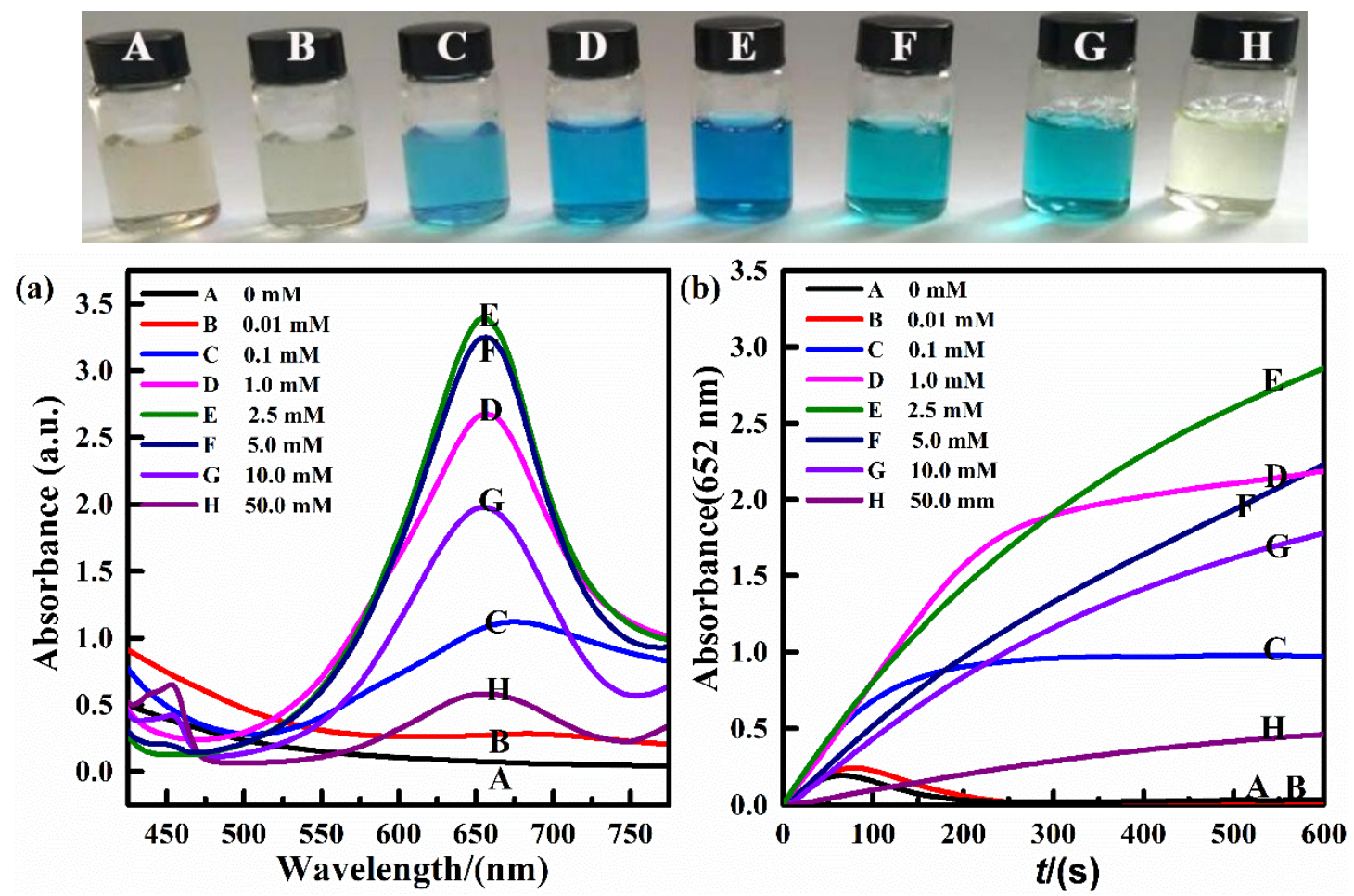

Figure S1. UV-vis spectra and time-dependent UV-vis absorbance $(652 \mathrm{~nm})$ for chromogenic catalysis of TMB-HRP- $\mathrm{H}_{2} \mathrm{O}_{2}$ occurred $10 \mathrm{~min}$ in sole SDS solutions. The corresponding color images of A-G on the top.

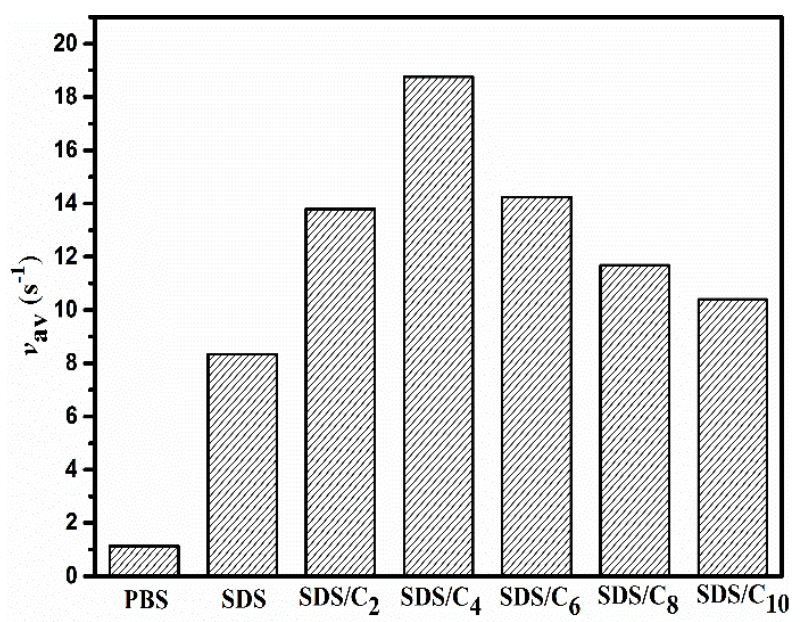

Figure S2. The mean formation rate of the blue chromogens within initial $100 \mathrm{~s}$ in different mediums corresponding to Figure 1(b). 


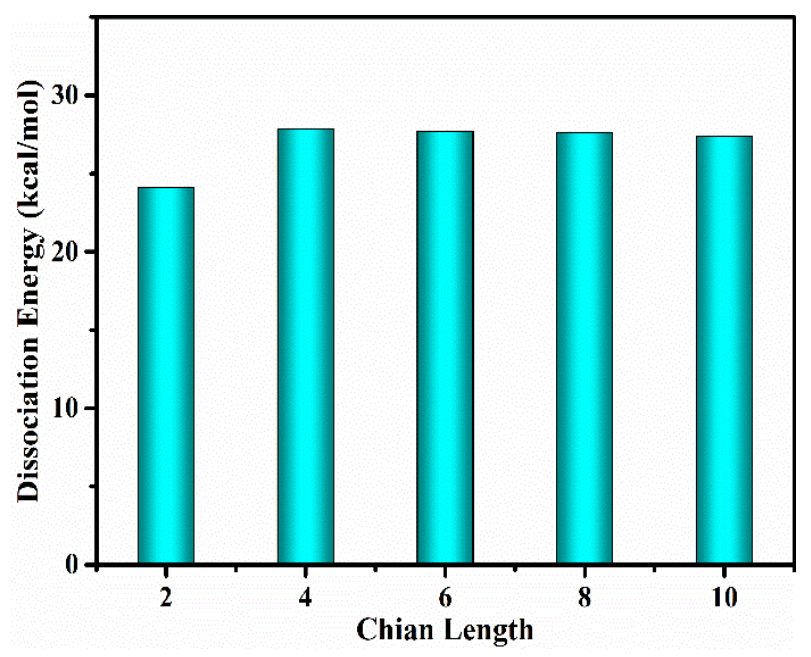

Figure S3. The dissociation energy $\left(E_{d}\right)$ of heme group with imidazole ring of His170 on native HRP when surrounded a $\left[\mathrm{C}_{\mathrm{n}} \operatorname{mim}\right](\mathrm{n}=2,4,6,8,10)$ group.

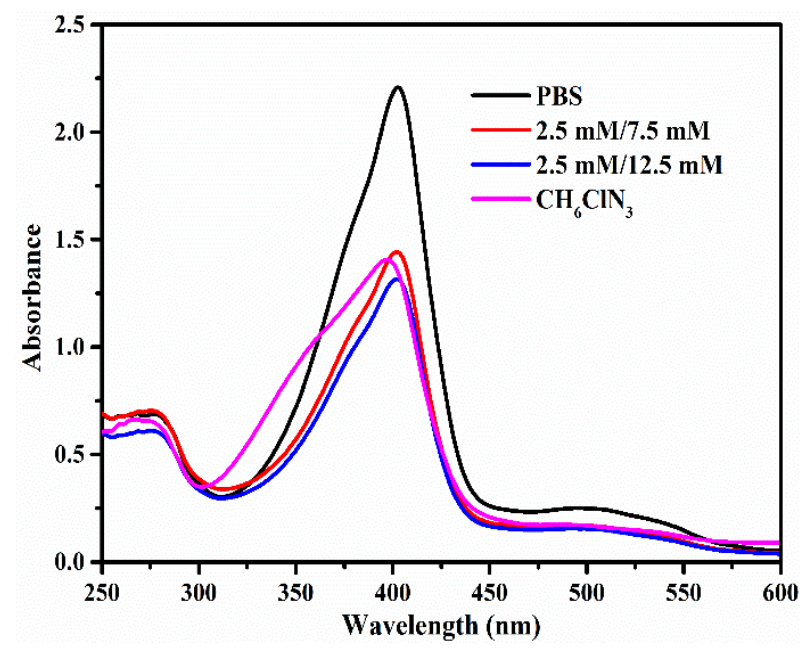

Figure S4. UV absorbance of HRP ( $1 \mathrm{~g} / \mathrm{L})$ in different mediums (PBS, $2.5 \mathrm{mM} \mathrm{SDS} / 7.5$ $\mathrm{mM}\left[\mathrm{C}_{4} \mathrm{mim}\right]\left[\mathrm{BF}_{4}\right], 2.5 \mathrm{mM} \mathrm{SDS} / 12.5 \mathrm{mM}\left[\mathrm{C}_{4} \mathrm{mim}\right]\left[\mathrm{BF}_{4}\right]$ and guanidine hydrochloride solution (enzyme inactivating agent)). 
Table S3 Comparison of various approaches for detection of $\mathrm{H}_{2} \mathrm{O}_{2}$ and glucose.

\begin{tabular}{|c|c|c|c|c|c|}
\hline \multirow[b]{2}{*}{ system } & \multicolumn{2}{|c|}{$\mathrm{H}_{2} \mathrm{O}_{2}$} & \multicolumn{2}{|c|}{ glucose } & \multirow[b]{2}{*}{ Ref. } \\
\hline & $\begin{array}{l}\text { Linear range } \\
\text { (M) }\end{array}$ & $\begin{array}{l}\text { LOD } \\
(\mathrm{M})\end{array}$ & $\begin{array}{c}\text { Linear range } \\
\text { (M) }\end{array}$ & $\begin{array}{l}\text { LOD } \\
(\mathrm{M})\end{array}$ & \\
\hline $\mathrm{Fe}_{3} \mathrm{O}_{4} \mathrm{MNPs}$ & $5 \times 10^{-6}-1 \times 10^{-4}$ & $3 \times 10^{-6}$ & $5 \times 10^{-5}-1 \times 10^{-4}$ & $3 \times 10^{-5}$ & 5 \\
\hline Positively charged AuNPs & $2 \times 10^{-6}-4 \times 10^{-4}$ & $5 \times 10^{-7}$ & $\begin{array}{l}1.8 \times 10^{-5}- \\
1.1 \times 10^{-3}\end{array}$ & $4 \times 10^{-6}$ & 6 \\
\hline SDS- $\mathrm{MoS}_{2}$ & $2 \times 10^{-6}-1 \times 10^{-4}$ & $3.2 \times 10^{-7}$ & $5 \times 10^{-6}-5 \times 10^{-4}$ & $\begin{array}{c}5.7 \times 10^{-} \\
7\end{array}$ & 7 \\
\hline $\mathrm{MoS}_{2} / \mathrm{GO}$ & $5 \times 10^{-8}-5 \times 10^{-5}$ & $2.5 \times 10^{-9}$ & $1 \times 10^{-6}-5 \times 10^{-5}$ & $\begin{array}{c}8.3 \times 10^{-} \\
7\end{array}$ & 8 \\
\hline $\begin{array}{c}\text { DNA/CuAl-LDH } \\
\text { nanohybrids }\end{array}$ & $2 \times 10^{-5}-2 \times 10^{-3}$ & $1.0 \times 10^{-5}$ & $4 \times 10^{-5}-2 \times 10^{-4}$ & $8 \times 10^{-6}$ & 9 \\
\hline MnSe-g- $\mathrm{C}_{3} \mathrm{~N}_{4}$ nanosheets & $\begin{array}{l}1.8 \times 10^{-5}- \\
1.8 \times 10^{-3}\end{array}$ & $1.8 \times 10^{-6}$ & $\begin{array}{l}1.6 \times 10^{-4}- \\
1.6 \times 10^{-3}\end{array}$ & $8 \times 10^{-6}$ & 10 \\
\hline $\mathrm{HRP}-\mathrm{SDS} /\left[\mathrm{C}_{4} \mathrm{mim}\right]\left[\mathrm{BF}_{4}\right]$ & $5 \times 10^{-7}-1 \times 10^{-4}$ & $2.0 \times 10^{-7}$ & $1 \times 10^{-6}-1 \times 10^{-4}$ & $1 \times 10^{-6}$ & $\begin{array}{l}\text { This } \\
\text { work }\end{array}$ \\
\hline
\end{tabular}

\section{REFERENCES}

(1) Hosoda, H.; Takaski, W.; OE, T.; Tsukamoto, R.; Nambara, T., A Comparison of Chromogenic Substrates for Horseradish Peroxidase as a Label in Steroid Enzyme Immunoassay. Chemical and pharmaceutical bulletin 1986, 34, 4177-4182.

(2) Qi, F.; Kreth, J., Methods to Study Antagonistic Activities among Oral Bacteria. Methods Mol Biol 2017, 1537, 203-218.

(3) Aumiller, W. M., Jr.; Davis, B. W.; Hatzakis, E.; Keating, C. D., Interactions of Macromolecular Crowding Agents and Cosolutes with Small-Molecule Substrates: Effect on Horseradish Peroxidase Activity with Two Different Substrates. J Phys Chem B 2014, 118, 10624-32.

(4) Gao, Y.; Liu, X.; Sun, L.; Xu, Y.; Yang, S.; Fan, C.; Li, D., Alleviated Inhibition of Single Enzyme in Confined and Crowded Environment. The Journal of Physical Chemistry Letters 2019, 10, 82-89.

(5) Wei, H.; Wang, E., $\mathrm{Fe}_{3} \mathrm{O}_{4}$ Magnetic Nanoparticles as Peroxidase Mimetics and Their Applications in $\mathrm{H}_{2} \mathrm{O}_{2}$ and Glucose Detection. Analytical Chemistry 2008, 80, 2250-2254.

(6) Jv, Y.; Li, B.; Cao, R., Positively-Charged Gold Nanoparticles as Peroxidiase Mimic and Their Application in Hydrogen Peroxide and Glucose Detection. Chemical Communications 2010, 46, 8017-8019.

(7) Zhao, K.; Gu, W.; Zheng, S.; Zhang, C.; Xian, Y., SdS-MoS ${ }_{2}$ Nanoparticles as Highly-Efficient Peroxidase Mimetics for Colorimetric Detection of $\mathrm{H}_{2} \mathrm{O}_{2}$ and Glucose.

Talanta 2015, 141, 47-52. 
(8) Peng, J.; Weng, J., Enhanced Peroxidase-Like Activity of $\mathrm{MoS}_{2} /$ Graphene Oxide Hybrid with Light Irradiation for Glucose Detection. Biosensors and Bioelectronics 2017, 89, 652-658.

(9) Chen, L.; Sun, K.; Li, P.; Fan, X.; Sun, J.; Ai, S., DNA-Enhanced Peroxidase-Like Activity of Layered Double Hydroxide Nanosheets and Applications in $\mathrm{H}_{2} \mathrm{O}_{2}$ and Glucose Sensing. Nanoscale 2013, 5, 10982-10988.

(10) Qiao, F.; Qi, Q.; Wang, Z.; Xu, K.; Ai, S., Mnse-Loaded G-C3n4 Nanocomposite with Synergistic Peroxidase-Like Catalysis: Synthesis and Application toward Colorimetric Biosensing of $\mathrm{H}_{2} \mathrm{O}_{2}$ and Glucose. Sensors and Actuators B: Chemical 2016, 229, 379-386. 